\title{
Wereldnieuws
}

Onder dit kopje geven we kennis van recente onderwijskundige publicaties van onze Nederlandse en Belgische collega's in de buitenlandse vakpers.

\section{Academic Medicine}

Beschikbaar op: http://www.academicmedicine.org.

1. 2007;82(9) en 2007;82(10) en (10S): geen onderwijskundige publicaties uit Nederland/Vlaanderen.

\section{Advances in Health Sciences Education}

Beschikbaar op: http://www.springerlink.com.

1. 2007;12(3): niet verschenen.

2. 2007;12(4): geen onderwijskundige publicaties uit Nederland/Vlaanderen.

\section{The Clinical Teacher}

Beschikbaar op:http://www.theclinicalteacher.com.

Geen nieuw nummer verschenen sinds 2007; 4(3).

\section{Education for Health}

Beschikbaar op: http://www.educationforhealth.net

Dit tijdschrift is sinds 01-01-07 alleen nog elektronisch beschikbaar (gratis).
1. Art B, Roo L de, Maeseneer J de. Towards Unity for Health Utilising Community-Oriented Primary Care in Education and Practice. Educ Health 7 (on line), 2007:74.

\section{Journal of General Internal Medicine}

Beschikbaar op http://www.blackwellpublishing.com/ journal.asp

1. $2007 ; 22(7), 2007 ; 22(8), 2007 ; 22(9), 2007 ; 22$ (11): geen onderwijskundige publicaties uit Nederland/ Vlaanderen.

2. Dijk N van, Boer KR, Wieling W, Linzer M, Sprangers MA. Reliability, Validity and Responsiveness of the Syncope Functional Status Questionnaire. J Gen Intern Med 2007;22(10):1280-5.

\section{Medical Education}

Beschikbaar op: http://www.mededuc.com.

1. Crossley J, Russell J, Jolly B, Ricketts C, Roberts C, Schuwirth L, Norcini J. 'I'm pickin'up good regressions': the governance of generalisability analyses. Med Educ 2007; 41(10):926-34.

2. Busari JO, Koot BG. Quality of clinical supervision as perceived by attending doctors in university and district teaching hospitals. Med Educ 2007;41 (10):957-64.

3. Rademakers JJDJM, Rooy $\mathrm{N}$ de, Cate OTJ ten. Senior medical students' appraisal of canMEDS competencies. Med Educ 2007;41 (10):990-4. 


\section{Medical Teacher}

Beschikbaar op: http://www.tandf.co.uk/journals/titles/ 0142159X.asp.

1. Malling B, Scherpbier AJJA, Ringsted C. What is the role of the consultant responsible for postgraduate education in the clinical department? Med Teach 2007;29(5):471-7.

\section{Patient Education and Counselling}

Beschikbaar op: http://www.elsevier.com/locate/ pateducou.

2. 2007;68(2): geen onderwijskundige publicaties uit Nederland/Vlaanderen.
3. Siwe K, Wijma K, Stjernquist M, Wijma B. Medical students learning the pelvic examination: Comparison of outcome in terms of skills between a professional patient and a clinical patient model. Patient Educ Couns 2007;68(3):211-7.

4. Fassaert T, Dulmen S van, Schellevis F, Bensing J. Active listening in medical consultations: Development of the Active Listening Observation Scale (ALOS-global). Patient Educ Couns 2007;68(3):25864.

\section{Teaching and Learning in Medicine}

Beschikbaar op: http://www.siumed.edu/tlm.

1. 2007;19(4): geen onderwijskundige publicaties uit Nederland/Vlaanderen. 